Ricardo Andrade, Influence of concentration in the elevation of boiling point of mango pulp

\title{
INFLUENCE OF CONCENTRATION IN THE ELEVATION OF BOILING POINT OF MANGO PULP (Mangifera indica L.)
}

\author{
INFLUENCIA DE LA CONCENTRACIÓN EN LA ELEVACIÓN DEL PUNTO DE \\ EBULLICIÓN DE PULPA DE MANGO (Mangifera indica L.)
}

\begin{abstract}
Ricardo D. Andrade 1 , Ramiro Torres², Everaldo J. Montes ${ }^{3}$, Omar A. Pérez ${ }^{4}$, Juan Mendoza ${ }^{5}$, Ramiro Baquero Recibido para publicación: 2 de noviembre 2014- Aceptado para publicación: 27 de Noviembre 2014
\end{abstract}

\section{RESUMEN}

El objetivo de este estudio fue determinar la elevación del punto de ebullición de la pulpa de mango, a concentraciones de sólidos solubles entre 13 y $55^{\circ}$ Brix, y presiones en un rango de 9.820x103 a 1.009 x $105 \mathrm{~Pa}$ (abs.). La pulpa fue procesada en un triturador con una malla de $1.5 \mathrm{~mm}$, para obtener una consistencia uniforme y fue concentrada en un rotaevaporador. $500 \mathrm{~mL}$ de la muestra de pulpa de mango fue introducida en el recipiente de evaporación. La temperatura y presión se registraron de forma continua, y los valores finales del punto de ebullición y su presión asociada se registraron después que la lectura fue constante durante al menos 5 minutos. Los datos experimentales se representan mediante la regla de Dühring, la ecuación de Antoine y el modelo empírico de Crapiste y Lozano. La elevación en el punto de ebullición era casi independiente de la presión, variando sólo con la concentración de pulpa. Los datos experimentales se ajustaron adecuadamente a la ecuación de Antoine (R2>0.98) y Crapiste y Lozano modelo (R2>0.88).

Palabras claves: Pulpa de mango, punto de ebullición, evaporación, ecuación de Antoine, regla de Duhring

\section{ABSTRACT}

The objective of this study was to determine the elevation in boiling point of mango pulp was measured at soluble solids concentrations between range 13 and $55^{\circ}$ Brix and pressures in the range $9.820 \times 103$ to $1.009 \times 105 \mathrm{~Pa}$ (abs.). The pulp was processed in a pulper with a $1.5 \mathrm{~mm}$ screen to obtain a uniform

\footnotetext{
${ }^{1}$ Chemical Engineering, Universidad del Atlántico, Colombia. PhD. Food Science and Technology, Universidad de Santiago de Chile. Affiliation: Universidad de Córdoba, Colombia. E-mail: rdandrade@correo.unicordoba.edu.co

${ }^{2}$ Chemical Engineering, Universidad del Atlántico, Colombia. Affiliation: Universidad de Córdoba, Colombia. E-mail: rtorres@correo.unicordoba.edu.co

${ }^{3}$ Chemical Engineering, Universidad del Atlántico, Colombia. Magister in Food Science and Technology, Universidad de Vicosa, Brasil. Affiliation: Universidad de Córdoba, Colombia. E-mail: ejmontes@correo.unicordoba.edu.co

${ }^{4}$ Chemical Engineering, Universidad del Atlántico, Colombia. Ph.D. in Food Science and Technology, Universidad de Vicosa, Brasil.

Affiliation: Universidad de Córdoba, Colombia. E-mail: oaperez@correo.unicordoba.edu.co

${ }^{5}$ Food Engineering, Universidad de Córdoba, Colombia. E-mail: jxmendoza@correo.unicordoba.edu.co

${ }^{6}$ Food Engineering, Universidad de Córdoba, Colombia. E-mail: rxbaquero@correo.unicordoba.edu.co
} 
consistency and concentrated in rotating evaporator. $500 \mathrm{~mL}$ sample of mango pulp was introduced into the boiling vessel. Temperature and pressure were continuously recorded, and final values for solution boiling point and associated pressure were registered after readings had been constant for at least 5 minutes. Experimental data are represented using the Duhring's rule, Antoine equation and empirical model Crapiste and Lozano. The elevation in boiling point was nearly independent of pressure, varying only with pulp concentration. Experimental data were adjusted appropriately to Antoine equation (R2>0.98) and Crapiste and Lozano model (R2>0.88).

Keywords: Mango pulp, boiling point, evaporation. Antoine equation, Duhring's rule

\section{INTRODUCTION}

Mango (Mangifera indica L.) is an agricultural product of great economic importance for different developing countries, with more than 28 million tons of annual fruit production in the world. It is considered as one of the three or four finest tropical fruits. Its extraordinary taste, flavor, color and texture make it special not only for its fresh consumption but also as an ingredient in fruit salads, ice creams, jams, and cakes. Generally, varieties with fibre-less flesh, golden yellow color, and pleasant mango flavor are preferred (Bon et al. 2010; Occeña-Po 2006).

In the food industry, knowledge of the physical properties of food is fundamental in analyzing the unit operations. They influence the treatment received during the processing and good indicators of other properties and qualities of food. Evaporation is a unit operation that eliminates a solvent from a liquid by boiling the solution in an apparatus called an evaporator. This thermal concentration is commonly used for liquid foods such as fruit juice, milk, and sugar solutions for three main purposes: to reduce the volume and the weight of the product, which subsequently reduces the cost of storage, packaging, and distribution; to increase the stability of liquid food by reducing water activity and as intermediate processing technique in the food industry (Ramos and lbarz 1998; Krupiczka et al. 2002; Prost et al. 2006).

Freshly squeezed juice is pumped into an evaporator where most of the water is removed through vacuum- assisted heating. Commercial evaporators typically have several stages that sequentially heat the juice to ever-higher temperatures and then rapidly cool it. Knowledge of the boiling point temperature of fruit juices for a wide range of concentrations is of primary importance to juice industries, as they make wide use of evaporation for juice concentration as well as for other equipment and process design (Gabas et al. 2008).

Boiling point elevation at a certain external pressure can be determined from a thermodynamic equation using the latent heat of vaporization and molar fraction of the food. However, the use of these equations requires knowledge of the proportions of specific components of the foods that cause changes in the boiling points (Barbosa-Cánovas et al. 2005). Literature data for elevation of boiling point of fruit juices at different concentrations were presented for blackberry juice (Gabas et al. 2008), apple juice (Capriste and Lozano 1988), concentrated thai tangerine juices (llagantileke et al. 1992) and grapefruit Juice (Telis-Romero et al. 2007).

The objective of this work was to experimentally study the elevation in boiling point of mango pulp (Mangifera indica L.) at various concentrations and pressures. Experimental data are represented using the Dühring's rule, Antoine equation and empirical model Crapiste and Lozano.

\section{MATERIALS AND METHODS}

\section{Sample preparation}

The fresh mangos (variety "pork") were acquired in a local market in Monteria 
(Colombia) and the pulp was extracted and homogenized by means of a semi-industrial machine fitted with a sieve of $1.75 \mathrm{~mm}$. Afterwards, the pulp was concentrated (13, $25,35,45,55^{\circ}$ Brix) in one rotating evaporator and maintained in refrigeration $\left(4^{\circ} \mathrm{C}\right)$ for their later use. The mango pulp composition, determined according to the AOAC's standards (AOAC 2000), presented the following results: moisture content $85.6 \%$ (w.b.); total soluble solids $11^{\circ}$ Brix; titratable acidity $0.88 \%$ (malic acid) and $\mathrm{pH}$ 3.63.

\section{Operation of equipment}

A schematic diagram of the apparatus used for experimental measurement, which is similar to that described by Telis-Romero et al. (2002), is shown in Figure 1. It was made of glass and consisted of a flat bottom flask (F) with three openings. Samples were introduced into the flask by means of tube A and heated in a bath thermostatic (model Lauda 100) with oil and magnetic stirrer. When the mango pulp extract reached boiling temperature, a recirculation flow was established between tubes $\mathrm{B}$ and $\mathrm{C}$. The liquid-vapor mixture freed from the liquid surface flowed up through tube B, thus heating the thermocouple installed in the well, which was connected to a temperature transmitter, interface and PC. Entrained liquid particles were trapped in compartment $\mathrm{D}$ and returned to flask $F$, allowing vapor to enter reflux condenser R. Condensed vapor also returned to flask $F$ through tube $C$ with valve $\mathrm{V}$ controlling the recirculation flow rate to keep the extract concentration constant. The condenser was connected to a vacuum pump (Stages Vacuum Pump Ce Model $2 \mathrm{FY}-2 \mathrm{~B}$ ), allowing pressure to vary up 9820 $\mathrm{Pa}$. Differential pressure transmitters were used to measure static pressure at two different positions in the vacuum tube.

Determination of boiling point elevation $500 \mathrm{~mL}$ sample of mango pulp was introduced into the boiling vessel. The cooling water flow was initiated in the reflux condenser, the vacuum pump was turned on with a valve regulated to provide pressure desired, and the pulp was mixed and heated slowly. Temperature and pressure were then continuously recorded, and final values for solution boiling point and associated pressure were registered after readings had been constant for at least 5 minutes. In order to check extract concentration, heating was periodically interrupted, the vessel was cooled down to room temperature, and a sample of fluid was removed for measurement of total soluble solids ( $\left.{ }^{\circ} \mathrm{Brix}\right)$.

\section{Statistical analysis.}

A complete randomized design was used (5x11), concentration in 5 levels $(13,25,35$, 45 and $55^{\circ}$ Brix) and pressure in 11 levels $(9820$ to $100880 \mathrm{~Pa}$ ), with three replications in each case. The experimental data were fitted to Antoine, and Capriste and Lozano equations. For each fitted model, the determination coefficient (R2) and sum of the squared residual (SSR) were analyzed..

\section{RESULTS AND DISCUSSION}

\section{Dühring diagrams}

The typical manner of presenting boiling point data on fluid foods consists of relating these values with the boiling temperature of water at the same pressure. In case of concentrated solutions composed of non-volatile solutes, it is possible to accurately determine the vapor pressure at any temperature by using Dühring diagrams of such type of solutions, drawn by using related experimental vapor pressuretemperature data. Therefore, at a constant concentration we have:

$$
T_{A}=m_{0}+m_{1} T_{A 0}(1)
$$

where TA and TAO are respectively the boiling temperatures of mango pulp and water at the same pressure; $\mathrm{m} 0$ and $\mathrm{m} 1$ are parameters determined experimentally.

In the Table 1 shows parameters of equation (1) for mango pulp, it is observed that $\mathrm{m} 1 \approx 1$, indicating that elevation in boiling point varies only with pulp concentration and is independent 
of pressure. In figure 2 shows $\triangle T B$ (TA-TAO) versus the boiling point of pure water, show that the slope was practically equal to zero $(\mathrm{m} 1 \approx 1)$ for lower concentrations, but considerable deviations began to occur at higher concentrations ( ${ }^{\circ}$ Brix $>35$ ).

\section{Antoine equation}

An empirical equation, with the same format of Antoine equation can be written as:

$$
\ln P=A \frac{B}{T_{A}+C}(2)
$$

where $P$ is the pressure $(P a)$; TA is the boiling temperature of mango pulp $(\mathrm{K}) ; \mathrm{A}, \mathrm{B}$, and $\mathrm{C}$ are empirical constants dependent on concentration.

In Table 2 shows values of constants Antoine equation for mango pulp, obtained by a nonlinear regression procedure. Determination coefficient $(\mathrm{R} 2=0.99)$ indicates a good correlation between the model and experimental data. However, it was not possible to establish a dependence of these constants as a function of total soluble solids of mango pulp; similar behavior showed the blackberry juice (Gabas et al. 2008), and grapefruit juice (Telis-Romero et al. 2007). But for concentrated apple juices (Moresi and Spinosi 1984), the empirical constants ( $A, B$ and $C$ ) were correlated with the equivalent sucrose weight fraction.

\section{Empirical model Crapiste and Lozano}

Crapiste and Lozano (1988) proposed an alternative approach to representing the elevation of boiling point of aqueous solutions, which consisted of adopting an empirical model that was simultaneously dependent on pressure and soluble solids concentration (equation 3 ).

$$
T_{B}=W \exp (W) P
$$

where $\Delta \mathrm{T}_{\mathrm{B}}$ is the elevation in boiling point $\left({ }^{\circ} \mathrm{C}\right)$; $W$ represents the mass concentration of soluble solids ( ${ }^{\circ}$ Brix); $\alpha, \quad \beta, \quad \gamma$, and $\delta$ parameters evaluated by nonlinear regression.

The experimental data were fitted $\left(R^{2}=0.88\right)$ to empirical model Crapiste and Lozano, and presented values of parameters $\alpha=1.23 \times 10^{-2}, \beta$ $=0.494, \gamma=3.29 \times 10^{-2}$, and $\delta=0.804$. Similar order of magnitude was observed for blackberry (Gabas et al. 2008) and apple juice (TelisRomero et al. 2002). Nevertheless, considerably different from those corresponding to grapefruit (Telis-Romero et al. 2007), and models solutions of sugar cane (Montes et al. 2007).

\section{CONCLUSIONES}

The elevation in boiling point varying with pulp mango concen-tration, showing considerable deviations at higher concentra-tions. Thus, the pressure influence should be taken into account in any proposed method for predicting boiling points of mango pulp, mainly at high concentrations of total soluble solids ( ${ }^{\circ}$ Brix $\left.>35\right)$.

Boiling point of the mango pulp is fitly represented by the An-toine equation. However, it was not possible to establish a de-pendence of the constants of Antoine equation as a function of total soluble solids of mango pulp. But, empirical model Crapiste and Lozano fits to the experimental data of elevation in boiling point; this model consists of a single equation which takes into account the dependence of the elevation in boiling point on pressure and concentration.

\section{REFERENCIAS}

[1]. AOAC. 2000. Official Methods of Analysis. Asocciation of Official Analytical Chemists. Washington, USA. 
[2]. Barbosa-Cánovas G.V., Juliano P., Peleg M. 2005. Engineering properties of foods. In: Food engineering. Encyclopedia of life support sciences (edited by G.V. BarbosaCánovas). EOLSS Publishers/UNESCO. Paris, France.

[3]. Bon J., Váquiro H., Benedito J., TelisRomero, J. 2010. Thermophysical properties of mango pulp (Mangifera indica L. Cv. Tommy Atkins). Journal of Food Engineering, 97(4): 563-568.

[4]. Crapiste G.H., Lozano J.E. 1988. Effect of concentration and pressure on the boiling point rise of apple juice and related sugar solutions. Journal of Food Science, 53(3): 865-868.

[5]. Gabas A.L., Sobral P.J.A., CardonaAlzate C., Telis V.R.N., Telis-Romero J. 2008. Influence of fluid concentration on the elevation of boiling point of blackberry juice, International Journal of Food Properties, 11(4): 865-875.

[6]. Ilagantileke S.G., Ruba Jr. A.B., Joglekar H.A. 1992. Boiling point rise of concentrated Thai tangerine juices. Journal of Food Engineering, 15(3): 235-243.

[7]. Krupiczka R., Rotkege A., Ziobrowski, Z. 2002. Heat transfer to evaporating liquid films within a vertical tube. Chemical Engineering and Processing, 41(1): 23-38.

[8]. Montes E., Torres R., Andrade R. 2007. Equation of Capriste and Lozano modified to predict the point of boiling increasing in solutions of sugar cane. Dyna, 74(153): 135-140.

[9]. Moresi, M., Spinosi, M. Engineering factors in the production of concentrated fruit juices 1 . Fluid physical properties of orange juices. 1980. International Journal of
Food Science \& Technology, 15(3): 265276.

[10]. Occeña-Po L.G. 2006. Banana, Mango, and Passion Fruit. In: Handbook of Fruits and Fruit Processing (edited by Y.H. Hui). Blackwell publishing. lowa, USA.

[11]. Prost J.S., Gonzalez M.T., Urbicain M.J. 2006. Determination and correlation of heat transfer coefficients in a falling film evaporator. Journal of Food Engineering, 73(4): 320-326.

[12]. Ramos A.M., Ibarz A. 1998. Density of juice and fruit puree as a function of soluble solids content and temperature. Journal of Food Engineering, 35(1): 57-63.

[13]. Telis-Romero J., Cabral R.A.F., Kronka G.Z., Telis V.R.N. 2002. Elevation on boinling point of coffe extract. Brazilian Journal of Chemical Engineering, 19(1): $119-126$

[14]. Telis-Romero, J., Cantú-Lozano, D., Telis, V.R.N., Gabas, A.L. 2007. Thermal Evaporation: Representation of rise in boiling point of grapefruit juice. Food Science and Technology International, 13: 225-229.

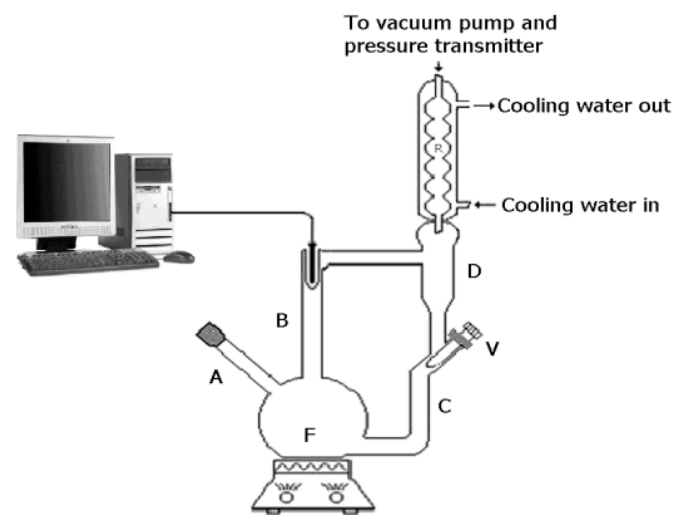


Ricardo Andrade, Influence of concentration in the elevation of boiling point of mango pulp

Figure 1. Schematic diagram of the apparatus used for the experimental measures.

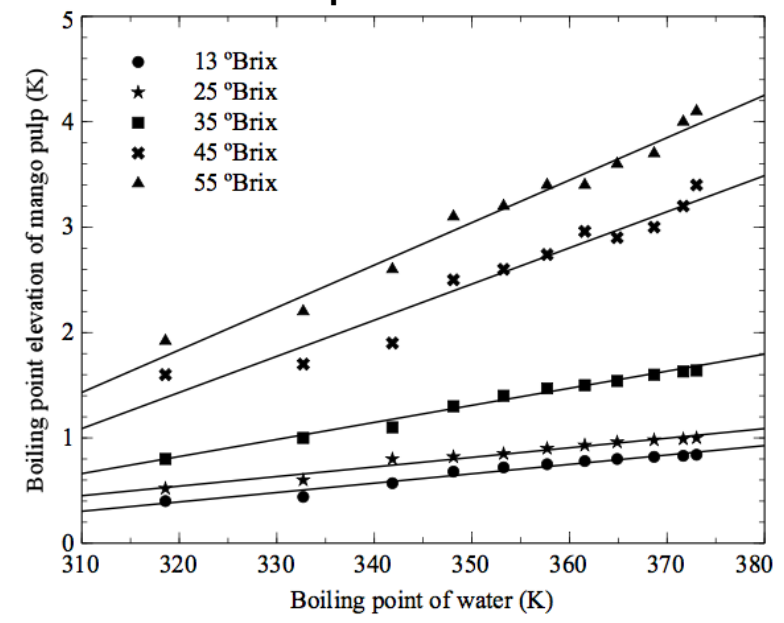

Figure 2. Boiling point elevation of mango pulp as a function of the boiling point of water

Table 1. Parameters of equation (1) for mango pulp

\begin{tabular}{clll}
\hline Concentration ('Brix) & $\mathrm{m}_{0}$ & $\mathrm{~m}_{1}$ & $\mathrm{R}^{2}$ \\
\hline 13 & -2.45 & 1.009 & 0.99 \\
25 & -2.37 & 1.009 & 0.99 \\
35 & -4.36 & 1.016 & 0.98 \\
45 & -9.55 & 1.030 & 0.97 \\
55 & -11.06 & 1.040 & 0.99 \\
\hline
\end{tabular}

Table 2. Constants of Antoine equation for mango pulp at different concentrations

\begin{tabular}{cllll}
\hline $\begin{array}{c}\text { Concentration } \\
\text { ('Brix) }\end{array}$ & $\mathrm{A}$ & $\mathrm{B}$ & $\mathrm{C}$ & $\mathrm{R}^{2}$ \\
\hline 13 & 17.54 & 12224.39 & - & 0.99 \\
25 & 24.33 & 4796.31 & -1.35 & 0.99 \\
& & & & \\
35 & 24.47 & 4952.33 & 6.43 & 0.99 \\
45 & 22.25 & 3513.08 & -49.47 & 0.99 \\
55 & 21.51 & 3051.86 & -71.65 & 0.99
\end{tabular}

